Roonwal, M.L. and G. Bose (1964). Termite fauna of Rajasthan, India. Zoologica 40(3)(Heft 113): 58+VI, 5pls.

Roonwal, M.L. and O.B. Chhotani (1962). Termite fauna of Assam region, Eastern India. Proceedings of natn. Institute of Science India 28: 282-406.

Roonwal, M.L. and S.C. Verma (1977). Re-survey of the termite fauna of Rajasthan, India, and its zoogeography. Records of the Zoological Survey of India 72: 425-480.

Snyder, T.E. (1949). Catalog of the termites (Isoptera) of the world. Smiths. Miscellaneous Collections 112: 490pp.

Thakur, M.L. (1976). Zoogeography of termite genus Odontotermes in the Indian Region (Isoptera: Termitidae: Macrotermitinae). Indian Forester 102(8): 498-505.

Thakur, M.L. (1981). Revision of the termite genus Odontotermes Holmgren (Isoptera: Termitidae: Macrotermitinae) from India. Indian Forest Records (N.S.) Entomology 14: 1-134.

Verma, S.C. and R.K. Thakur (1982). Termites from Madhya Pradesh, India, with new distributional records. Records of the Zoological Survey of India 79: 311-318

Wasmann, E. (1902). Termiten, Termitophilen und Myrmecophilen. Gesammelt auf Ceylon von Dr. W. Horn. Zool. Jb. 17: 99-164.

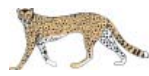

VET BRIEF

ZOOS' PRINT JOURNAL 21(11): 2482

\section{EGG BINDING IN AN ALEXANDRINE PARAKEET PSITTACULA EUPATRIA}

\section{Nath ${ }^{1}$, T.K. Pattnaik ${ }^{2}$, V.S.C. Bose ${ }^{3}$, M.R. Das ${ }^{4}$ and S.K. Panda ${ }^{5}$}

${ }^{1,2}$ Associate Professor; ${ }^{3}$ Professor, Department of Surgery;

${ }^{4}$ Assistant Professor, Department of Medicine; ${ }^{5}$ Assistant

Professor, Department of Pathology, Orissa Veterinary College,

Bhubaneswar, Orissa 751003, India

Email: ${ }^{1}$ indravet@yahoo.co.in

plus web supplement of 1 page

Egg binding or obstruction of oviduct occurs in all avian species. Hypocalcaemia may be an important factor in seed eating cage birds. This is an emergency condition that must be dealt with rapidly (Fowler, 1985). The present paper reports a case of egg binding in an Alexandrine Parakeet Psittacula eupatria.

A female parrot aged about 15 years was presented to the surgery clinic of Orissa Veterinary College with prolapse of cloaca. History revealed that the parrot was depressed with ruffled feathers and standing straddle-legged on the floor of the cage, restlessly moving back and forth. On examination an egg wrapped in the oviduct and presented through the cloacal opening was marked (Image $1^{\mathrm{w}}$ ).

The condition was diagnosed as a case of egg binding and it was decided to release the egg by surgery. The parrot was restrained manually. One hand was used to hold the head securely by placing thumb and forefinger on the lateral surface of mandible, while the other hand was used to control the body and legs. The prolapsed cloaca was irrigated with cold normal saline. Then the terminal part of the oviduct covering the egg and a portion of cloacal wall was given a small nick with a sterile b.p. blade (Image $2^{\mathrm{w}}$ ) and the egg was released by gentle manipulation without breaking the shell (Image $3^{\mathrm{w}}$ ).

The oviduct and cloacal walls were left unsutured which relapsed to their normal position (Image $4^{\mathrm{w}}$ ). Multivitamin 2 drops (ABDEC drop 15ml, Pharmapake, Pfizer India Ltd, Mumbai) was administered orally thrice daily for five days along with oral cephalexin powder 30mg (Ceff DT 125mg, Lupine Lab, Mumbai) for three days. The parrot recovered uneventfully.

In the present case as the bird was depressed, physical restraint was used to control the parrot without chemical restraint. Immediate operation by incising the terminal oviduct wall and cloacal wall released the egg binding and saved the life of the parrot as obstruction of oviduct is an emergency situation in which immediate death may result from compression of large blood vessels of intestine or ureteral blockage as suggested by Fowler (1985). Since it was a caged parrot eating soaked peanuts, maize and seasonal fruits, the diet might have resulted in hypocalcaemia thereby causing egg binding.

\section{REFERENCE}

Fowler, M.E. (1985). Surgical Principles and technique in Non-domestic Animals, pp. 1075-1076. In: Gourley, I.M and P.B.Vasseur (Eds.). General Small Animal Surgery, $1^{\text {st }}$ edn. J.B. Lippincott Company, Philadelphia.

\section{ACKNOWLEDGEMENT}

Authors are thankful to L.A.K. Singh, Senior Research Officer and K.L. Purohit, Range Officer, o/o the Chief Wild Life Warden, Orissa for their valuable suggestions.

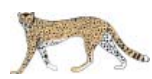

w See Images in the web supplement at www.zoosprint.org

(c) Zoo Outreach Organisation; www.zoosprint.org Manuscript 1554; Received 07 April 2006; Revised received 11 August 2006; Finally accepted 10 October 2006; Date of publication 21 October 2006 